\title{
TINJAUAN HUKUM ISLAM TERHADAP PENERAPAN GOOD GOVERNANCE DALAM PELAYANAN PUBLIK
}

\author{
Sri Warjiyati \\ Universitas Islam Negeri Sunan Ampel Surabaya \\ Fakultas Syariah dan Hukum \\ Program Studi Hukum Tata Negara \\ Email: warjiatisri@gmail.com
}

\begin{abstract}
The concept of good governance in of Islamic law perspective is more directed to how to leverage the methods offered in Ushul Fikih to formulate the principles of Islamic law to respond to various problems that occur in government. The number of issues, which occur in government governance, therefore it required to examine the reality of the current state of government in order to be better, professional, responsible, trustworthy, one of them by building the concept of good governance in the hope of contributing to the development of better bureaucratic governance in accordance with principles and values in Islamic law, such as equality, tasamuh (tolerance), justice, welfare, deliberation (syura), honesty, objectivity (comprehensiveness) and this is an indication of good and clean governance. The approach used is the proposal of Fikih proposal as an epistemological and philosophical basis in Islamic law by describing new theories of Ficih as an applied theory in exploring the values of public service in another term can be called clean governance in the perspective of Islamic law.
\end{abstract}

Keywords: Islamic law, government, good governance, clean governance

\begin{abstract}
ABSTRAK
Konsep good governance dalam tinjauan hukum Islam lebih mengarah kepada bagaimana cara mendayagunakan metode yang ditawarkan dalam ilmu Ushul Fikih untuk merumuskan asas-asas hukum Islam untuk merespons berbagai persoalan yang terjadi dalam pemerintahan.. Banyaknya persoalan, yang terjadi dalam tata kelola pemerintah, oleh karena itu kita dituntut untuk mengkaji realitas kondisi pemerintahan saat ini agar lebih baik, professional, bertanggungjawab, amanah, salah satunya dengan cara membangun konsep good governance dengan harapan memberikan kontribusi bagi pengembangan tata kelola birokrasi yang lebih baik sesuai dengan prinsip dan nilai-nilai dalam hukum Islam, seperti nilai kesetaraan, tasamuh(toleransi), keadilan (justice), kemaslahatan, musyawarah (syura), kejujuran (honesty), objektif (comprehensiveness) dan ini menjadi indikasi terbentuknya pemerintahan yang bersih dan baik (good and clean governance). Pendekatan yang digunakan adalah pendekatan Usul Fikih sebagai landasan epistemologis dan filosofis dalam hukum Islam dengan menjabarkan teori baruushul Fikih sebagai aplikasi teori
\end{abstract}


(applied theory) dalam menggali nilai-nilai menunju pelayanan publik dalam istilah lain dapat disebut clean governance dalam perspektif hukum Islam .

Kata kunci: hukum Islam, pemerintahan, good governance, clean governance

\section{PENDAHULUAN}

Dalam suatu negara fungsi pemerintah sangat penting. Apabila pemerintah tidak berfungsi secara baik, maka akan berpengaruh besar terhadap kestabilan suatu negara. Oleh karena itu, pemerintah harus dipegang oleh orang-orang yang mengerti mengenai fungsi pemerintah tersebut.Fungsi pemerintah bisa dilihat dari definisi pemerintah tersebut.Pemerintah merupakan organisasi yang memiliki kekuasaan untuk membuat dan menerapkan hukum serta undang-undang diwilayah tertentu.Pemerintah mempunyai kekuasaan dan lembaga yang mengurus masalah kenegaraan dan kesejahteraan rakyat. ${ }^{1}$

Good governance merupakan paradigma baru dalam sistem pemerintahan dan harapan setiap masyarakat supaya terwujudnya pemerintahan yang baik. Perwujudan good governance merupakan citacita masyarakat dan sejalan dengan ajaran Islam.Oleh sebab itu, untuk mewujudkan pemerintahan yang baik, maka peran serta masyarakat sangat dibutuhkan, karena hubungan antara pemerintah dengan masyarakat merupakan satu kesatuan yang tidak dapat dipisahkan. Disamping itu, sektor swasta sangat menentukan terwujudnya pemerintahan yang baik, karena swasta merupakan pelaku dalam mewujudkan pembangunan.

Konsepsi good governance menghendaki agar dalam menghadapikompleksitas masyarakat yang ada, penyelengggaraan pemerintahan perluditekankan pada fungsi koordinasi dan komposisi.Dalam hal ini,pemerintah diarahkan untuk melakukan pengendalian (steering) dankolaborasi mengingat dinamika masyarakat (pola intraksi salingmengendalikan diantara berbagai faktor yang terlibat atau yangberkepentingan dalam suatu bidang tertentu).Sedangkan

1 Muhammadong. 2017, Good Governance Dalam Perspektif Hukum Islam, Makasar: Edukasi Mitra Grafika, hal. 2. 
kondisikeragaman masyarakat dapat diatasi dengan penyelenggaraanpemerintahan yang menekankan pada pengaturan (regulation) danintegrasi atau keterpaduan. ${ }^{2}$

Dalam aktualisasi konsep good governance, peranan dari pemerintah perlu dibekali dengan kemampuan dan kompetensi untuk menjembatanikonflik diantara berbagai kelompok kepentingan dan berbagai hambatan lainnya dalam rangka sosial politik. Pemerintah harus mampu mendelegasikan tanggung jawab makro sudut pandang administrasi,politis, ilmiah, dan sosial mengenai pembangunan) terhadap berbagaiunsur sosial.Dan pada saat bersamaan, berusaha mendorong dan memberdayakannya untuk mengambil dan menerima tanggung jawab tersebut. ${ }^{3}$

Reformasi birokrasi dalam pemerintahan merupakan langkah awal untuk mewujudkan pemerintahan yang baik (good governance), transparan, dan akuntable masih mengalami banyak hambatan. Terutama masih merebaknya praktik korupsi, kolusi, dan nepotisme masih banyak terjadi di pemerintahan . Secara historis, factor agama juga mempunyai peran penting dalam mewujudkan civil society untuk mewujudkan tata kelola pemerintahan yang baik (good governance).

Terciptanya sebuah pemerintahan yang bersih dan berwibawamerupakan hal yang sangat dibutuhkan, guna membentuk negeri yang dapat melindungi segenap bangsa, selain dapat memajukan kesejahteraan umum, dan mencerdaskan kehidupan bangsa, sebagaimana tertuang dalam pembukaan UUD 1945. Untuk menuju kepada pemerintahan yang bersih dan berwibawa tersebut diperlukan pengelolaan berbagai bidang kehidupan seperti politik, hukum, ekonomi, sosial dan budaya secara lebih serius, transparan, dan terarah serta melibatkan semua komponen bangsa guna bersama-sama bangkit dari keterpurukan dan kehinaan di mata dunia internasional. ${ }^{4}$

Penyelenggaraan pemerintahan dalam good governance berkaitan dengan isu transparansi, akuntabilitas publik, dan sebagainya. Secara konseptual dapat dipahami bahwa good governance menunjukkan suatu proses yang memposisikan rakyat dapat

\footnotetext{
${ }^{2}$ Muhammadong. 2017, Good Governance Dalam Perspektif Hukum Islam, (Makasar: Edukasi Mitra Grafika), hal. 98.

${ }^{3}$ Ibid, hal. 99.

${ }^{4}$ Nur Rohim Yunus, Menciptakan Good and CleanGovernmentBerbasis Syariah Islamiyah dalamTatakelola Pemerintahan RepublikIndonesia, jurnal Nur El-Islam, Volume 3 Nomor 1 April 2016, hal. 145.
} 
mengatur ekonominya. Institusi serta sumber sosial dan politiknya tidak hanya sekedar dipergunakan untuk pembangunan, tetapi juga untuk menciptakan integrasi bagi kesejahteraan rakyat. Good governance juga dipahami sebagai suatu penyelenggaraan manajemen pemerintahan yang solid dan bertanggung jawab yang sejalan dengan prinsip demokrasi dan pasar, pemerintahan yang efisien, serta pemerintahan yang bebas dan bersih dari kegiatan korupsi, kolusi, dan nepotisme $(\mathrm{KKN})^{5}$

Mewujudkan pemerintahan yang baik bukan merupakan pekerjaan yang mudah karena memerlukan proses. Good governance merupakan kebutuhan penting yang harus diwujudkan dalam sistem pemerintahan, karena tingginya ekspektasi masyarakat terhadap good governance demi tercapainya tata pemerintahan yang baik. Untuk mewujudkan good governance, diperlukan manajemen yang baik dalam mewujudkan pemerintahan. Ide menyelenggarakan good governance dapat terlaksana jika kembali pada nilai-nilai Islam. Keberadaan hukum Islama adalah penyelesaian atau sedikitnya menjadi jalan tengah untuk menyelesaikan masalah berbangsa dan bernegara. Hukum Islam mempunyai realitas sebagai hukum yang berdiri sendiri dalam masyarakat. Melalui peninjauan hukum Islam, dapat digali norma-norma hukum Islam yang berkaitan dengan hakikat dan prinsip good governance. Dalam penelitian ini, akan dibahas analisis good governance dalam perspektif tinjauan hukum Islam.

\section{Hakikat Good Governance}

Secara bahasa, pengertian good berarti baik, dalam istilah kepemerintahan mengandung dua pemahaman. Pemahaman pertama, nilai-nilai yang menjunjung tinggi keinginan dan kehendak rakyat dan nilai-nilai yang dapat meningkatkan kemampuan rakyat dalam pencapaian tujuan nasional, kemandirian, pembangunan

\footnotetext{
${ }^{5}$ Juniarso Ridwan \& Ahmad Sodik Sudrajat. 2009, Hukum Administrasi Negara dan Kebijakan Pelayan Publik, (Bandung: Nuansa), hal. 81-82.
} 
berkelanjutan dan keadilan sosial. Kedua, aspek-aspek fungsional dan pemerintahan yang efektif dan efisien dalam pelaksanaan tugasnya untuk mencapaitujuan tersebut ${ }^{6}$.

Sedang government secara istilah adalah proses pengambilan keputusan dan proses bagaimana sebuah keputusan diimplementasikan. Good Governance diartikan sebagai governance yang baik.Governance dapat digunakan dalam berbagai konteks diantaranya Coorporate Governance, Government Governance, international governance,nasional governance dan lokal governance. ${ }^{7}$

Istilah "governance" sebenarnya sudah dikenal dalam literature administrasi dan ilmu politik hampir 120 tahun yang lalu, sejak Woodrow Wilson, yang kemudian menjadi Presiden Amerika Serikat ke 27, memperkenalkan bidang studi tersebut kirakira 125 tahun yang lalu. Tetapi selama itu governance hanya digunakan dalam literatur politik dengan pengetian yang sempit. ${ }^{8}$

Dalam kamus, istilah "government" dan "governance" seringkali dianggap memiliki arti yang sama yaitu cara menerapkan otoritas dalam suatu organisasi, lembaga atau negara. Government (pemerintahan) juga adalah nama yang diberikan kepada entitas yang menyelenggarakan kekuasaan pemerintahan dalam suatu negara. Governance diartikan sebagai mekanisme, praktek dan tata cara pemerintahan dan warga mengatur sumber daya serta memecahkan masalah masalah publik. Dalam konsep governance, pemerintah hanya menjadi salah satu actor dan tidak selalu menjadi aktor yang menentukan. ${ }^{9}$

Secara konseptual pengertian good dalam istilah good governance mengandung dua pemahaman.Pertama, nilai yang menjunjung tinggi keinginanatau kehendak rakyat serta nilai-nilai yang dapat meningkatkankemampuan rakyat dalam

\footnotetext{
${ }^{6}$ Sunarya, Impelementasi Good Government dan Clean Governance dalamPenyelenggaraan Pemerintahan, (Jakarta: Irjen Depag, 2007), hal.72.

${ }^{7}$ Dwi Martini, Good Governance Dalam Pelayanan Publik, dalam buku yangberjudul Konsep, Strategi dan Implementasi Good Governance Dalam Pemerintahan, (Jakarta: Irjen Depag RI, 2007), h.4-5.

${ }^{8}$ Ahmad Syaini, "Good Governance dalam Perspektif Fiqh Kontemporer", dalam http://achmadsyaini.blogspot.com/2010/04/hadispolitik. html?zx=10782e662f255ac2. Diakses tanggal 3juni 2018.

${ }^{9}$ Joko Setyono, Good Governance Dalam Perspektif Islam; Pendekatan Ushul Fikih: Teori Pertingkatan Norma, Jurnal Muqtasid, Volume 6, Nomor 1, Juni 2015, h. 31
} 
mencapai tujuan nasional, kemandirian pembangunanyang berkelanjutan dan keadilan sosial.Kedua, aspek fungsionaldari pemerintah yang efektif dan efisien dalam pelaksanaan tugasnya untukmewujudkan tujuan nasional (Ubaidullah, 2004:113-114). Sisi lain memaknai good governance sebagai penerjemahan kongkrit dari demokrasi. Istilah governance dalam konteks good governance terkadang dipersamakan dengan government sehingga muncul istilah good government. Padahal konsep governance mempunyai pengertian (makna) yang berbeda dengan government. Kata government merupakan suatu kata yang menunjuk pada suatu organisasi pengelolaan berdasarkan kekuasaan tertinggi (negara dan pemerintah), sedangkan kata "governance" tidak hanya melibatkan pemerintah tetapi juga peran berbagai aktor diluar pemerintah, sehingga pihak-pihak yang terlibat juga sangat luas. $^{10}$

Kajian good governance dapat diintegrasikan dengan ushul fiqh, yaitu dengan menggali nilai-nilai filosofis (the theory values) norma dalam hukum Islam sangat penting untuk dikaji. Dalam pembahasan ini, akan dikaji tentang teori pertingkatan norma sebagai pendekatan ushul fikih, selanjutnya membahas tentang pengertian dan konsep good governance dengan mengintegrasikan dengan pendekatan ushul fiqh dan pada bagian akhir akan dibahas tentang good governance perspektif Islam. Tulisan ini dapat memberikan warna, bahwa hukum Islam (ushul fiqh) selalu berkembang dan mampu menjawab tantangan modernitas yang berkarakter continyuty and change.Artinya, ushul fiqh tetap memperhatikan realitas masyarakat (living law), sehingga melahirkan rumusan hukum Islam yang humanis dan otoritatif (bukan otoritarianisme hukum Islam). ${ }^{11}$

\section{Prinsip-Prinsip Good Governance}

10 Joko Widodo. 2001, Good Governance, Telaah dari Dimensi Akuntabilitas da Kontrol Birokrasi pada Era Desentralisasi dan Otonomi Daerah (Surabaya: Insan Cendekia), hal. 141.

11 Amin Abdullah,.Pendekatan Hermeneutik dalam Studi Fatwa-Fatwa Keagamaan: Proses Negosiasi Komunitas Pencari Makna Teks, Pengarang, dan Pembaca”, dalam Pengantar buku Khaled M. AbouEl-Fadl. 2004, Atas Nama Tuhan dari Fikih Otoriter ke Fikih Otoritatif, (Jakarta: Serambi, hal. 27 
Penerapan konsep good governance pada akhirnya mensyaratkan keterlibatan organisasi kemasyarakatan sebagai kekuatan penyeimbang Negara.Namun cita good governance pada saat ini merupakan bagian yang sangat serius dalam wacana pengembangan paradigma birokrasi dan pembangunan kedepan. Karena peranan implementasi dari prinsip good governance adalah untuk memberikan mekanisme dan pedoman dalam memberikan keseimbangan bagi para stakeholders dalam memenuhi kepentingannya masing-masing.

Dalam penyelenggaraan good governance menghendaki adanya akuntabilitas, transparansi, keterbukaan dan rule of law. Sementara pemerintahan yang bersih menuntut terbebasnya praktik yang menyimpang (mal-administration) dari etika administrasi negara.Sedangkan pemerintah yang beriwibawa menuntut adanya ketundukan,ketaatan, dan kepatuhan (compliance) rakyat terhadap undang-undang, pemerintah dan kebijakan pemerintah, sedangkan pemerintah yang beribawa berkaitan dengan ketaatan, kepatuhan, dan ketundukan masyarakat kepada pemerintah, peraturan perundang-undangan, dan kebijakan yang dibuat oleh pemerintah. Ketaatan, ketundukan, dan kepatuhan masyarakat, sering muncul atau ditemukan karena pemerintah menggunakan otoritas kekuasaan yang mereka miliki. ${ }^{12}$

Prinsip-prinsip good governance pada dasarnya mengandung nilai yang bersifat obyektif dan universal yang menjadi acuan dalam menentukan tolok ukur atau indikator dan ciri-ciri/karekteristik penyelenggaraan pemerintahan negara yang baik. Prinsip-prinsip good governance dalam praktek penyelenggaraan negara sesuai dengan maksud UU Nomor 28 Tahun 1999 tentang Penyelenggaraan negara yang bersih dan bebas korupsi, kolusi dan nepotisme. Dalam hubungan ini, kata prinsip mempunyai makna yang sama dengan asas, karena asas dan atau prinsip pada hakekatnya merupakan awal suatu kebenaran yang menjadi pokok dasar tujuan berpikir, berpendapat, dan bertindak. ${ }^{13}$

Good governance merupakan suatu kondisi dalam mana terwujud hubungan tiga unsur, yaitu pemerintah (government), rakyat atau masyarakat sipil (civil society),

\footnotetext{
12 Pandji Santosa. 2008, Administrasi Publik:Teori dan Aplikasi Good Governace, (Bandung: Refika Aditama), hal. 17.

${ }^{13}$ Muhammadong, Good Governance Dalam Perspektif Hukum Islam, ibid, hal. 100.
} 
dan dunia usaha yang berada disektor swasta yang sejajar, berkesamaan dan berkesinambungan di dalam peran yang saling mengontrol. Untuk itu dikemukakan beberapa prinsip-pronsip yang dapat diidentifikasikan untuk menandai apa yang disebut good governance. ${ }^{14}$

United Nations Depelopment Program (UNDP) menyatakan bahwa untuk mewujudkan pemerintahan yang baik (good governance) perlu menerapkan prinsip penyelenggaraan pemerintahan dengan mengacu pada prinsip dasar, yaitu sebagai berikut : Pertama, partisipasi (Participation) yaitu, setiap orang atau warga masyarakat, baik laki-laki mapun perempuan memiliki hak suara yang sama dalam proses pengambilan keputusan, baik secara langsung maupun melalui lembaga perwakilan seduai dengan kepentingan dan aspirasinya masing-masing.Kedua, Penegakan hukum (Rule Of Low). Dalam pelaksanaan tidak mungkin dapat berjalan dengan kondusif apabila tidak ada sebuah hukum atau peraturan yang ditegakkan dalam penyelenggaraannya.Aturan-aturan itu berikut sanksinya guna meningkatkan komitmen dari semua pihak untuk mematuhinya.Ketiga, Transparansi (Transparancy) yaitu, transparansi harus dibangun dalam rangka kekebasan aliran informasi.

Keempat, Daya Tanggap (Resvonsiveness) yaitu, setiap institusi dan prosesnya harus diarahkan pada upaya untuk melayani berbagai pihak yang berkepentingan (stakeholders).Kelima, Berorientasi Konsensus (Consensus Orientation) yaitu, pemerintah yang baik akan bertindak sebagai penengah terhadapberbagai kepentingan yang berbeda untuk mencapai consensus atau kesepakatan yang terbaik bagi kepentingan masing-masing pihak, dan jika dimungkinkan dapat diberlakukan terhadap berbagai kebijakan dan prosedur yang akan ditetapkan pemerintah.

Keenam, Berkeadilan (Equity) yaitu, pemerintah yang baik akan memberi kesempatan yang baik terhadap laki-laki maupun perempuan dalam upaya mereka untuk meningkatkan dan memelihara kualitas hidupnya. Ketujuh, Efektivitas dan Efisiensi (Effectivennes and Efficiency) yaitu, setiap proses kegiatan dan

${ }^{14}$ Ahmad Zayyadi, 1 Juni 2017, Good Governance Dalam Perspektif Hukum Islam Kontemporer (Tinjauan Usul Fikih dari Teori Pertingkatan Norma), Jurnal al-Manahij, Vol. XI No. 1, hal. 16. 
kelembagaan diarahkan untuk menghasilkan suatu yang benar-benar sesuai dengan kebutuhan melalui pemanfaatan sebaik-baiknya berbagai sumber yang tersedia. Kedelapan, Akuntabilitas (Accountability) yaitu, para pengambil keputusandalam organisasi sektor publik, swasta, dan masyarakat madani memiliki pertanggungjawaban (akuntabilitas) kepada public (masyarakat umum), sebagaimana halnya kepada para pemilik (stakeholders). ${ }^{15}$

\section{Good Governace dalam Perspektif Hukum Islam}

Dalam pandangan hukum Islam, good governance merupakan gerakan Ijtihadi.Oleh karena itu, untuk mewujudkan pemerintahan yang baik, maka konsep maslahat mursalah merupakan acuan dalam sistem pemerintahan.Konsep maslahat mursalah sangat sesuai dengan kondisi dan tempat demi mewujudkan suatu kemaslahatan dalam pemerintahan, sehingga dapat tercipta pemerintahan yang baik, Karena semua kebijakan-kebijakan yang diambil oleh pemerintah untuk kebaikan masyarakat yang dipimpinnya.

Persoalan good governance tidak lepas dari figh siyasah atau siyasah syar'iyah, karena penetapan hukumnya mengacu kepada kemaslahatan dan kepentingan manusia.Titik persamaan antara fikih siyasah dengan good governance terletak pada system pengaturan, pengendalian, dan pelaksanaa dalam suatu negara atau wilayah.Good governance sejalan dengan teori maqasid al-syariah, yaitu; yaitu, hifz al-din (menjaga agama), hifz al-nafs (menjaga jiwa), hifz al-'aql (menjaga akal), hifz al-nasl (menjaga keturunan), dan hifz al-mal (menjaga harta). Karena pada prinsipnya good governance mempunyai tujuan yang sama dengan maqasid alsyariah. $^{16}$

Good governance merupakan bagian dari fikih siyasah, karena semua kebijakan yang yang diambil oleh pemerintah berdasarkan hasil pemikiran manusia untuk mewujudkan kemaslahatan rakyat dan terhindar dari kemudaratan. Disamping itu, implementasi kebijakan yang diambil pemerintah tentu sejalan dengan ajaran

15 Ilham Rifai Hasan. 2008, Urgensi Penerapan Manajemen PembangunanNasional Pada Lini Lokal, (Jakarta: Colloqium Ketahanan nasional RI), hal. 111-112.

${ }^{16}$ Muhammadong, Good Governance Dalam Perspektif Hukum Islam, ibid, hal. iii. 
Islam supaya cita-cita goodgovernance dapat tercapai.Hubungan fikih siyasah dengan goodgovenance terletak pada sistem pengaturan, pengendalian, dan pelaksanaan dalam suatu negara atau wilayah.Dalam fikih siyasah, kebijakan atau keputusan selalu didasarkan kepada ajaran Islam atau wahyu Ilahi (top down), sedangkan good governance berangkat dari pemikiran manusia (bottom up). ${ }^{17}$

Dalam prespektif hukum Islam, good governance dapat dikatakan sebagai sebuah ijtihad yang dilakukan dalam rangka mencapai maslahah yang menjadi tujuan syari'at (maqashid syariah) ${ }^{18}$. Maslahah tersebut adalah terciptanya suatu penyelenggaraan manajemen pembangunan yang solid dan bertanggungjawab yang sejalan dengan prinsip demokrasi dan pasar yang efisien, penghindaran salah alokasi dana investasi, dan pencegahan korupsi baik secara politik maupun administratif menjalankan disiplin anggaran serta penciptaan legal and political frame work bagi tumbuhnya aktivitas usaha. ${ }^{19}$

Dalam konsep maslahah juga dibahas dalam kaidah qowaid fiqiyah, yaitu:

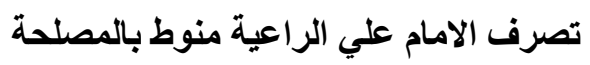

Artinya : "kebijakan seorang pemimpin terhadap rakyatnya adalah berkaitan dengan Kemaslahatan".

Kaidah ini adalah kaedah khusus dalam bidang siyasah.Maksud kaedah ini adalah tindakan pemerintah harus berorientasi pada kemaslahatan umat. Good governance yang diwacanakan dan diterapkan dalam birokrasi sebagai sebuah upaya dari pemerintah dan masyarakat merupakan sebuah tindakan yang berorientasi maslahah. Penguatan nilai-nilai akuntabilitas, transparansi, supremasi hukum, dan

\footnotetext{
${ }^{17} \mathrm{Ibid}$, hal. 30.

${ }^{18}$ Maqâshid asy-Syarî’ah adalah tujuan syariat Islam, yang memiliki sasaran kemaslahatan bagi manusia. Ia dapat disimpulkan menjadi lima hal yang biasa dikenal dengan sebutan al-kulliyyâtul al-khamsah, yaitu sebagai berikut: 1). Hifzh ad-Din (preservation of religion), yaitu menjaga agama dari kemusyrikan, kekufuran,dan segala bentuk kerusakan akidah. 2). Hifzh an-Nafs (preservation of life), yaitu menjaga kehidupan dan jiwa raga. 3). Hifzh an-Nasl (preservation of progeny), yaitu menjagaketurunan. 4). Hifzh al-Mâl (preservation of wealth), yaitu menjaga harta benda dan kekayaan yang diperoleh secara sah. 5). Hifzh al- 'Aql (preservation of intellect), yaitu menjaga akal dari segala aksi yang dapat merusaknya. [Lihat: Abu Ishaq Asy-Syâtibhi, Al-Muwâfaqat fi al-Ushûl asSyarî'ah, (maktabah al-ashriyyah, Juz II), hal. 8.

${ }^{19}$ Nur Rohim Yunus, Menciptakan Good and Clean Government Berbasis Syariah Islamiyah dalam Tatakelola Pemerintahan Republik Indonesia, jurnal, Nur El-Islam, Volume 3 Nomor 1 April 2016, hal. 170.
} 
partisipasi publikdalam pelaksanaan birokrasi publik menjadikan lembaga semakin kuatdan dapat menghasilkan manfaat yang maksimal. Dengan penguatan lembaga dan manfaat yang dihasilkan semakin kuat dirasakan oleh masyarakat, maka kebijakan pemerintah menjadikan konsep good and clean governance dapat diterapkan dalam lembaga-lembaga publikdan telah mendasarkan kebijakannya atas maslahat umat. ${ }^{20}$

Hakikat good governance dalam pandangan fikih, pada dasarnya belum ditemukan rumusan baku. Namun terdapat ayat yang mengidikasikan adanya persoalan good governance dalam ajaran Islam. Hal itu dapat dilihat dalam firman Allah swt dalam surah al-Hajj/QS.22:41,

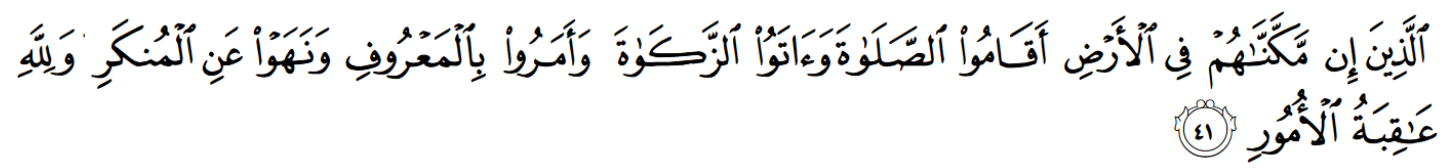

Artinya :orang-orang yang jika Kami teguhkan kedudukan mereka di muka bumi niscaya mereka mendirikan sembahyang, menunaikan zakat, menyuruh berbuat ma'ruf dan mencegah dari perbuatan yang mungkar dan kepada Allah lah kembali segala urusan. ${ }^{21}$

Ayat tersebut mengindikasikan adanya persoalan good governance dalam pandangan fikih, karena penggunaan otoritas kekuasaan untukmengelola pembangunan dengan berorientasi pada (1) penciptaan suasanakondusif bagi masyarakat untuk pemenuhan kebutuhan spiritual danrohaninya dapat disimbolkan dengan penegakan sholat, (2) penciptaankemakmuran dan kesejahteraan ekonomi dapat dilambangkan dengantindakan membayar zakat, (3) penciptaan stabilitas politik dan keanana dapat diilhamkan dengan tindakan amar ma'ruf nahi munkar. Dengandemikian ayat tersebut merumuskan good governance dengan tiga aspek,yaitu; (1) spiritual governance, (2) economic governance (3) political governance. $^{22}$

\footnotetext{
${ }^{20}$ Nur Rohim Yunus, Menciptakan Good and Clean Government Berbasis Syariah Islamiyah dalam Tatakelola Pemerintahan Republik Indonesia ,ibid, hal. 173.

${ }^{21}$ Departemen Agama RI, al-Qur,an terjemahan,hal. 469.

${ }^{22}$ Muhammad Iqbal, Fikih Siyasah Kontekstualisasi Doktrin Politik Islam Cet. I; Jakarta: Radar Jaya Pratama, 2001, ibid, hal. 19.
} 
Dalam persoalan good governance, pendekatan yang dilakukan adalah maslahah mursalah, karena metode tersebut sangat sesuai dengan kondisidan tempat demi mewujudkan suatu kemaslahatan dalam pemerintahan sehingga dapat tercipta pemerintahan yang baik.Karena semua kebijakankebijakan yang diambil oleh pemerintah untuk kebaikan masyarakat yang dipimpinnya.

Good governance sebagai sebuah upaya maslahah haruslahmemenuhi beberapa kriteria yang disimpulkan dari penjelasan beberapapakar ushul fiqh, yaitu sebagai berikut : Pertama, kemaslahatan haruslah sesuai dengan maqhashid alsyari'ah, semangat ajaran, dalil-dalil kulli dan dalil-dalil qath'i, baik wurud maupun dalalah-nya. Prinsip-prinsip good governance seperti yang telah dilihat di atas dapat ditemukan dalam nash-nash syariat. Hal ini menunjukkan bahwa good governance sebagai sebuah maslahat telah memenuhi prinsip kesesuaian dengan maqhashid alsyari'ah.Kedua, kemaslahatan harus meyakinkan arti kemaslahatan ituberdasarkan penelitian yang cermat dan akurat, sehingga tidak meragukan bahwa hal itu dapat mendatangkan manfaat dan menghindarkan mudharat.Beberapa nilai good governance telah dipraktekkan oleh nabi Muhammad dalam negara Madinah, Hasilnya adalah bahwa negara Madinah dapat menjadi berkembang dan membawa kemajuan bagi Islam pada waktu itu dan beberapa abad kemudian. Ketiga, kemaslahatan membawa kemudahan dan bukan mendatangkan kesulitan yang di luar batas, dalam arti kemaslahatan itu bisa dilaksanakan. Nilai-nilai good governancetelah menjadi bagian yang diperintahkan oleh Alquran.Ini dapat berarti bahwa perintah-perintah tersebut adalah sejalan dengan kemampuan manusia untuk melaksanakannya. ${ }^{23}$

\section{PENUTUP}

Dalam pandangan hukum Islam, good governance merupakan gerakan Ijtihady.Oleh karena itu, untuk mewujudkan pemerintahan yang baik, maka konsep maslahat mursalah merupakan acuan dalam sistem pemerintahan.Konsep maslahat

\footnotetext{
${ }^{23}$ Nur Rohim Yunus, Menciptakan Good and Clean Government Berbasis Syariah Islamiyah dalam Tatakelola Pemerintahan Republik Indonesia ,ibidh. hal 172.
} 
mursalah sangat sesuai dengan kondisi dan tempat demi mewujudkan suatu kemaslahatan dalam pemerintahan, sehingga dapat tercipta pemerintahan yang baik, karena semua kebijakankebijakan yang diambil oleh pemerintah untuk kebaikan masyarakat yang dipimpinnya.

Persoalan good governance tidak lepas dari fiqh siyasah atau siyasah syar'iyah, karena penetapan hukumnya mengacu kepada kemaslahatan dan kepentingan manusia.Titik persamaan antara fikih siyasah dengan good governance terletak pada sistem pengaturan, pengendalian, dan pelaksanaan dalam suatu negara atau wilayah.Good governance sejalan dengan teori maqasid al-syariah, yaitu; memelihara agama, memelihara jiwa, memelihara akal, memelihara keturunan, dan memelihara harta. Karena pada prinsinya good governance mempunyai tujuan yang sama dengan maqasid al-syariah.

\section{DAFTAR PUSTAKA}

Abdullah Amin,2004, Pendekatan Hermeneutik dalam Studi Fatwa-Fatwa Keagamaan: Proses Negosiasi Komunitas Pencari Makna Teks, Pengarang, dan Pembaca", dalam Pengantar buku Khaled M. AbouEl-Fadl, Atas Nama Tuhan dari Fikih Otoriter ke Fikih Otoritatif, Jakarta: Serambi.

Asy-Syâtibhi Abu Ishaq, Al-Muwâfaqat fi al-Ushûl as-Syarî'ah,(maktabah alashriyyah, Juz II.

Hasan Ilham Rifai, 2008, Urgensi Penerapan Manajemen Pembangunan Nasional Pada Lini Lokal Jakarta: Colloqium Ketahanan nasional RI.

Iqbal Muhammad,2001, Fikih Siyasah Kontekstualisasi Doktrin Politik Islam Cet. I; Jakarta: Radar Jaya Pratama,

Martini Dwi,2007, Good Governance Dalam Pelayanan Publik, dalam buku yang berjudul Konsep, Strategi dan Implementasi Good Governance Dalam Pemerintahan, (Jakarta: Irjen Depag RI.

Muhammadong,2017, Good Governance Dalam Perspektif Hukum Islam, Makasar: Edukasi Mitra Grafika.

Ridwan Juniarso \& Sudrajat Ahmad Sodik,2009,Hukum Administrasi Negara dan Kebijakan Pelayan Publik, Bandung: Nuansa.

Santosa Pandji,2008, Administrasi Publik:Teori dan Aplikasi Good Governace, Bandung: Refika Aditama.ssssssssss

Setyono Joko,2015, Good Governance Dalam Perspektif Islam; Pendekatan Ushul Fikih: Teori Pertingkatan Norma, Jurnal Muqtasid, Volume 6, Nomor 1, Juni. Sunarya,2007, Impelementasi Good Government dan Clean Governance dalam Penyelenggaraan Pemerintahan, Jakarta: Irjen Depag. 
Widodo Joko,2001,Good Governance, Telaah dari Dimensi Akuntabilitas da Kontrol Birokrasi pada Era Desentralisasi dan Otonomi Daerah (Surabaya: Insan Cendekia.

Yunus Nur Rohim,2016, Menciptakan Good and Clean Government Berbasis Syariah Islamiyah dalam Tatakelola Pemerintahan Republik Indonesia, jurnal Nur El-Islam, Volume 3 Nomor 1 April.

Zayyadi Ahmad,2017, Good Governance Dalam Perspektif Hukum Islam Kontemporer (Tinjauan Usul Fikih dari Teori Pertingkatan Norma), Jurnal alManahij, Vol. XI No. 1, Juni. 